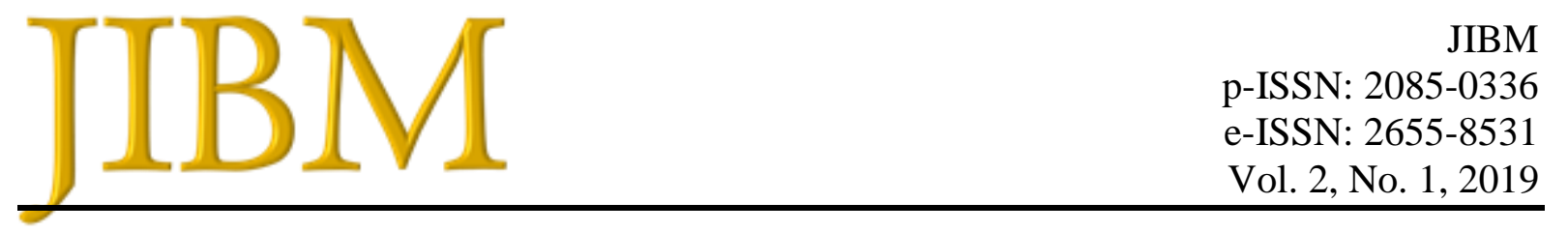

\title{
Pengaruh Konflik dan Budaya Organisasi Terhadap Kinerja Pada Badan Pendapatan Daerah Provinsi Sumatera Selatan
}

\author{
Tri Antika \\ Universitas PGRI, Palembang \\ Email: triantika111@gmail.com \\ Tri Sinarti \\ Universitas PGRI, Palembang
}

\begin{abstract}
Performance, knowing the Effect of Organizational Culture on Performance and knowing the effect of Conflict and Organizational Culture on Performance in the Regional Revenue Agency of the Province of South Sumatra.This study uses a questionnaire as a data collection technique with the number of samples used by 51 employees. This study uses the help of SPSS Version 22 software to analyze data The results of the t-test analysis show that the value of the Conflict variable (X1) is 3,619, and the organizational culture is 4,185 so the value of tcount $>t$ table is 3,619> 1,676 with a significance level of $0.001<0.05$ for Conflict (X1) and 4,185> 1,676 for Culture Organization (X2) with a significance level of $0,000<0,05$, then Ho is rejected and Ha is accepted which means that the conflict partially has a significant effect on employee performance and Organizational Culture partially has a significant effect on employee performance. Based on the results of the $\mathrm{F}$ test obtained Fcount value of 17.180 with a Ftable value of 3.16, the value of Fcount $>$ Ftable is $17.180>3.19$. Significance value $=0.000^{\mathrm{b}}$ $<\alpha=0.05$ then Ho is rejected and Ha is accepted, meaning that there is a significant influence between Conflict and Organizational Culture on Employee Performance. Furthermore, the R square value obtained is 0.417, which means that employee performance at the Regional Revenue Agency can be explained by Conflict and Organizational Culture of $41.7 \%$, while the remaining $58.3 \%$ is explained by other variables not included in this study, such as motivation, environment work and training. This shows that the free variables (Conflict and Organizational Culture) only provide part of the information needed to predict the dependent variable (Performance).
\end{abstract}

Keywords: Conflict, organizational culture, performance

\begin{abstract}
Abstrak
Penelitian ini bertujuan untuk mengetahui pengaruh Konflik terhadap Kinerja, mengetahui Pengaruh Budaya Organisasi terhadap Kinerja dan mengetahui pengaruh Konflik dan Budaya Organisasi terhadap Kinerja yang pada Badan Pendapatan Daerah Provinsi Sumatera Selatan. Penelitian ini menggunakan kuesioner sebagai teknik pengumpulan datadengan jumlah sampel yang digunakan sebesar 51 pegawai. Penelitian ini menggunkan bantuan perangkat lunak SPSS Versi 22 untuk mengalisis data. Hasil analisis uji t menunjukkan nilai thitung variabel Konflik $\left(\mathrm{X}_{1}\right)$ bernilai 3,619, dan Budaya organisasi bernilai 4,185 sehingga nilai dari $t_{\text {hitung }}>t_{\text {tabel }}$ yaitu 3,619 > 1,676 dengan taraf signifikansi $0,001<0,05$ untuk variabel Konflik $\left(\mathrm{X}_{1}\right)$ dan 4,185 > 1,676 untuk Budaya Organisasi $\left(\mathrm{X}_{2}\right)$ dengan taraf signifikansi $0,000<0,05$ maka $\mathrm{H}_{\mathrm{o}}$ ditolak dan $\mathrm{H}_{\mathrm{a}}$ diterima yang artinya Konflik secara parsial berpengaruh signifikan terhadap Kinerja pegawai dan Budaya Organisasi secara parsial berpengaruh signifikan terhadap Kinerja pegawai. Berdasarkan hasil uji $\mathrm{F}$ didapat nilai $\mathrm{F}_{\text {hitung }}$ sebesar 17,180 dengan nilai $\mathrm{F}_{\text {tabel }}$ sebesar 3,16 maka nilai $F_{\text {hitung }}>F_{\text {tabel }}$ yaitu 17,180 $>3.19$. Nilai signifikansi $=0.000^{\mathrm{b}}<\alpha=0,05$ maka $\mathrm{H}_{\mathrm{o}}$ ditolak dan $\mathrm{H}_{\mathrm{a}}$ diterima, artinya ada pengaruh yang signifikan antara Konflik dan Budaya Organisasi terhadap Kinerja Pegawai. Selanjutnya diperoleh nilai $R$ square sebesar 0,417 yang berarti bahwa Kinerja pegawai pada Badan Pendapatan Daerah dapat dijelaskan oleh Konflik dan Budaya Organisasi sebesar 41,7\%, sedangkan sisanya 58,3\% dijelaskan oleh variabel lain yang tidak termasuk dalam penelitian ini, seperti motivasi, lingkungan kerja dan pelatihan. Hal ini menunjukkan bahwa varibel bebas (Konflik dan Budaya Organisasi) hanya memberikan sebagian informasi yang dibutuhkan untuk meprediksi variabel terikat (Kinerja).
\end{abstract}

Kata kundi: konflik, budaya organisasi, kinerja

\section{Pendahuluan}

Suatu organisasi tidak akan lepas dari tenaga kerja manusia, karena manusia adalah penggerak utama jalannya suatu organisasi. Meskipun berbagai unsur telah tersedia dalam organisasi, jika tanpa adanya peran manusia maka suatu organisasi tidak akan berjalan. Oleh karena itu, sumber daya manusia disebut sebagai asset yang sangat penting. Organisasi seringkali mengharapkan 


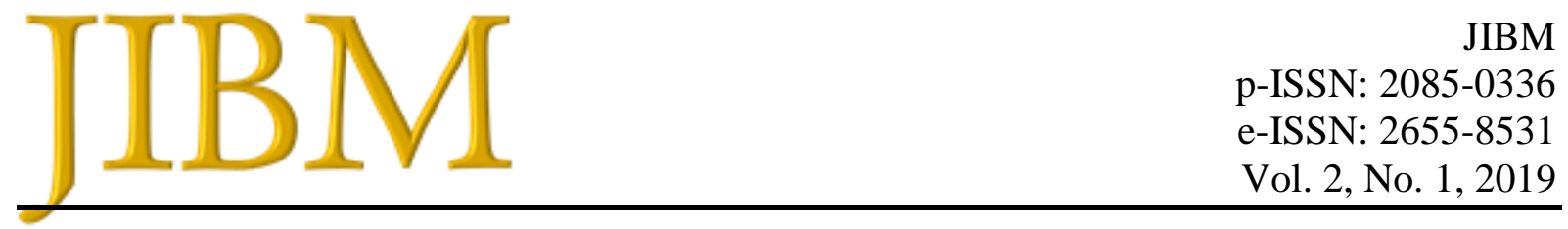

kinerja yang optimal dari para pegawai hingga mampu menghasilkan berbagai prestasi yang akan meningkatkan reputasi organisasi.

Organisasi memiliki sifat responsif terhadap perubahan yang terjadi di lingkungan sekitar. Sehingga perubahan dari luar akan cepat mempengaruhi lingkungan internal organisasi, yang mana perubahan-perubahan tersebut muncul dengan terencana maupun tidak terencana sebagai upaya organisasi untuk berdaptasi dengan perkembangan yang ada.

Sebagaimana perubahan sistem kerja yang seringkali terjadi di Badan Pendapatan Daerah yang mengharuskan pegawai untuk beradaptasi kembali dengan lingkungan kerja yang baru, agar dapat memahami serta menjalankan tugas sesuai dengan fungsinya dan diselesaikan sesuai dengan waktu yang telah ditetapkan. Ketika proses adaptasi sering terjadi adanya kesalahan komunikasi pada subbag Keuangan dalam kegiatan mengelola anggaran keluar untuk setiap kegiatan daerah Provinsi maupun Kabupaten, dikarenakan pegawai yang bersangkutan belum memahami tugasnya. Selain itu, perubahan juga menyebabkan adanya ketergantungan kerja terhadap salah satu pegawai yang sebelumnya pernah ditugaskan di subbag keuangan, karena pegawai tersebut dianggap memiliki kemampuan lebih dibandingkan dengan pegawai yang baru dipindahkan.

Perubahan merupakan suatu hal yang tidak mudah diterima oleh sebagian orang. Mereka menganggap perubahan akan berdampak negatif pada kinerja, karena merasa tidak ada kesesuaian pada lingkungan baru yang akan berakibat pada penurunan etos kerja dalam melaksanakan tugas-tugas yang seharusnya diselesaikan. Kesulitan yang mungkin dialami pegawai dalam beradaptasi akan memicu munculnya Konflik dalam dirinya, karena etos kerja yang menurun didasari pada pribadi seseorang yang bermasalah, dan akan berpengaruh pula pada komunikasi antar personal seperti yang telah terjadi pada subbag keuangan.

Selain dari Konflik, salah satu faktor yang mempengaruhi kinerja adalah Budaya Organisasi. Setiap organisasi akan menampakkan sifat dan cirinya berdasarkan karakteristik budaya organisasi yang dimilikinya (Wibowo, 2014: 35). Melalui budaya organisasi yang dianut akan membuat kesadaran diri anggota, pemahaman serta pemikiran yang sejalan antar sesama anggota organisasi. Sehingga akan menciptakan tim yang baik dalam menjalankan visi untuk mencapai tujuan organisasi. Oleh karena itu, budaya organisasi harus diperkenalkan kepada pegawai baru. Kemudian, budaya organisasi juga dapat diukur melalui kepribadian pegawai dalam menjalankan pekerjaan agar sesuai dengan budaya yang dianut. Dilihat dari beberapa kondisi, kepribadian seringkali mendorong munculnya pandangan yang berbeda dalam satu tim yang akan berdampak pada orientasi tim menjadi turun. Berdasarkan uraian diatas, maka peneliti tertarik untuk melakukan penelitian yang berjudul "Pengaruh Konflik dan Budaya Organisasi terhadap Kinerja Pegawai Pada Badan Pendapatan Daerah Provinsi Sumatera Selatan".

\section{Literature Review}

\subsection{Pengertian Konflik}

Handoko (2011) menjelaskan, bahwa konflik organisasi (organizational conflict) adalah ketidaksesuaian antara dua atau lebih anggota-anggota atau kelompok-kelompok organisasi yang timbul karena adanya kenyataan bahwa mereka harus membagi sumber daya-sumber daya yang terbatas atau kegiatan-kegiatan kerja dan/atau karena kenyataan bahwa mereka mempuyai perbedaan status, tujuan, atau persepsi. 


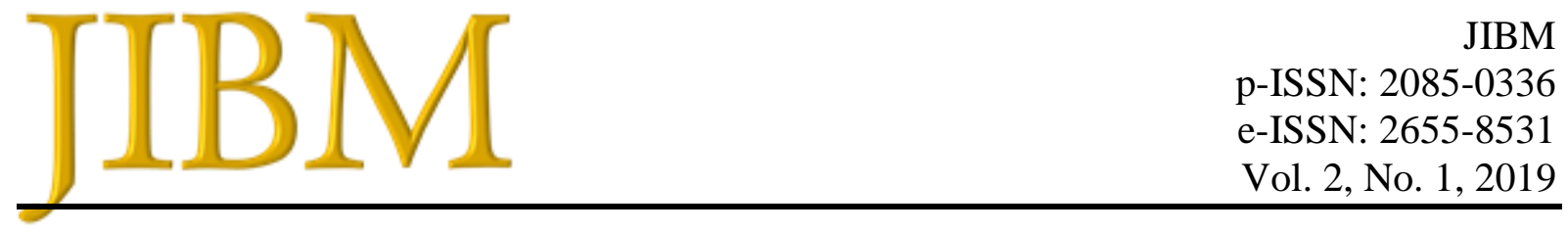

Pada kenyataannya, konflik merupakan sesuatu yang tidak bisa dihindari dalam kehidupan setiap individu ataupun kelompok karena konflik dianggap sebagai warisan kehidupan sosial. Hal ini dilatar belakangi oleh terciptanya manusia sebagai makhluk sosial yang selalu melakukan interaksi. Dengan beragam sifat dan karakter yang dimiliki oleh manusia dapat menimbulkan perbedaan tujuan serta persepsi yang memicu munculnya suatu konflik. Demikian pula dengan kehidupan organisasi, dimana dalam mencapai tujuan para pegawai harus selalu melakukan interaksi.

\subsubsection{Faktor-faktor Konflik}

Konflik terjadi akibat berbagai sebab dan alasan, Aldag dan Stearns dalam Putra (2015) mengidentifikasi sumber-sumber konflik yang meliputi task inderdependence, goal incompatibility, differentiation of values and point of view, uncertainly (the shifting of the task scope), and reward system" artinya tugas saling bergantungan, ketidakcocokan tujuan, perbedaan nilai dan sudut pandang, ketidakpastian (pergeseran lingkup tugas) dan sistem penghargaan. Sejalan dengan pendapat Marwansyah (2012:305-308) yang mengungkapkan bahwa faktor-faktor penyebab konflik dapat dikategorikan dalam dua faktor yaitu faktor-faktor organisasi dan faktor-faktor antar pribadi:

1) Faktor-faktor organisasi, yang meliputi: a) persaingan SDM; b) ketidakjelasan tanggung jawab; c) ketergantungan dan d) sistem Imbalan.

2) Faktor-faktor antar pribadi, yang meliputi: a) iri hati atau dendam; b) salah anggapan; c) komunikasi yang buruk dan d) kritik yang tidak tepat.

\subsection{Pengertian Budaya Organisasi}

Menurut Drucker dalam Umam (2010), budaya organisasi adalah pokok penyelesaian masalah-masalah eksternal dan internal yang pelaksanaannya dilakukan secara konsisten oleh suatu kelompok yang kemudian mewariskan kepada anggota-anggota baru sebagai cara yang tepat untuk memahami, memikirkan, dan merasakan terhadap masalah-masalah terkait seperti diatas. Hal tersebut didukung oleh pendapat David dalam Arianty (2014) yang menyatakan bahwa budaya organisasi merupakan pola tingkah laku yang dikembangkan oleh suatu organisasi yang dipelajarinya ketika mengalami masalah adaptasi eksternal dan integrasi internal, yang telah terbukti cukup baik utuk disahkan dan diajarkan kepada anggota baru sebagai cara untuk menyadari, berpikir dan merasa.

Kemudian Edison, Anwar dan Komariyah (2017) berpendapat bahwa, budaya organisasi merupakan hasil proses melebur gaya budaya dan atau perilaku tiap individu yang dibawa sebelumnya ke dalam sebuah norma-norma dan filosofi yang baru, yang memiliki energi serta kebanggaan kelompok dalam menghadapi sesuatu dan tujuan tertentu. Sedangkan kekuatan dari budaya organisasi itu sendiri sangat bergantung pada nilai-nilai konstruktif yang dibangun dan memengaruhi cara mereka bertindak. Bahkan budaya ini tidak hanya dipahami anggotanya, tapi juga harus diterima dan diperkenalkan pada saat rekrutmen, sehingga calon pegawai atau karyawan menyadari bahwa ia akan memasuki suatu arena yang berbeda dengan segala tantangannya. Goffee and Jones dalam Mansur (2013) membagi budaya organisasi menjadi empat kuadran (tipe budaya) yaitu: (1) Networked, (2) Fragmented, (3) Mercenary, dan (4) Communal.

\subsection{Pengertian Kinerja}

Menurut Mathis dan Jackson dalam Komaling, dkk (2016) kinerja adalah seberapa banyak para pegawai memberi konstribusi kepada perusahaan meliputi kuantitas output, kualitas output, 


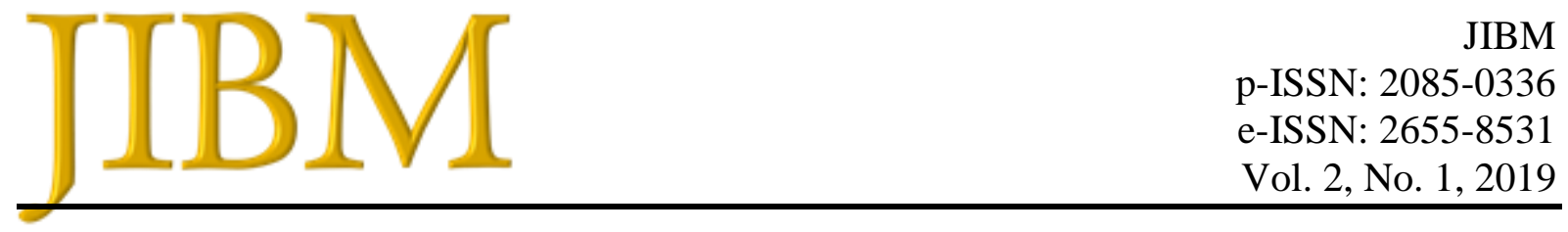

jangka waktu, kehadiran ditempat kerja dan sikap kooperatif. Kinerja pegawai merujuk pada kemampuan pegawai dalam melaksanakan keseluruhan tugas-tugas yang menjadi tanggung jawabnya Sedangkan Mangkunegara dalam Septianto (2010) kinerja adalah hasil kerja secara kualitas dan kuantitas yang dicapai oleh seorang pegawai dalam melaksanakan tugasnya sesuai dengan tanggung jawab yang diberikan kepadanya. Sejalan dengan pendapat Edison, Anwar dan Komariyah (2017), bahwa kinerja adalah hasil dari suatu proses yang mengacu dan diukur selama periode waktu tertentu berdasarkan ketentuan atau kesepakatan yang telah ditetapkan sebelumnya.

Dapat disimpulkan bahwa, kinerja merupakan tolak ukur keberhasilan dalam mencapai tujuan organisasi. Kinerja dinilai sebagai kontribusi pegawai kepada organisasi, dengan menjalankan setiap tugas dan tanggung jawab yang telah disepakati sebelumnya secara profesional. Kontribusi pegawai dapat dilihat dari sikap kooperatif (kerjasama) terhadap rekan kerja serta kedisiplinan yang akan membuat pegawai memiliki output yang berkualitas.

\section{Metodologi Penelitian}

Penelitian ini menggunakan metode penelitian kuantitatif. Menurut Sugiyono (2016), metode penelitian kuantitatif dapat diartikan sebagai metode penelitian yang berlandaskan pada filsafat positivisme, digunakan untuk meneliti pada populasi atau sampel tertentu, teknik pengambilan sampel pada umumnya dilakukan secara random, pengumpulan data menggunakan instrumen penelitian, analisis data bersifat kuantitatif/statistik dengan tujuan untuk menguji hipotesis yang telah ditetapkan. Berdasarkan metode ini, diperoleh data primer dan data sekunder yang didapat dari responden melalui kuesioner dan berbagai dokumentasi objek penelitian. Jawaban responden terhadap pertanyaan dalam media kuesioner dalam bentuk checklist diukur dengan menggunakan skala Likert. Menurut Sugiyono (2016), skala Likert digunakan untuk mengukur sikap, pendapat dan persepsi seseorang atau sekelompok orang tentang fenomena sosial yang selanjutnya disebut sebagai variabel penelitian. Skala likert dimulai dari skala 1 (sangat tidak setuju) sampai dengan skala 5 (sangat setuju).

Pengujian hipotesis penelitian ini menggunakan Regresi Linier Multiple. Menurut Kurniawan (2014), persamaan Regresi Linier Multiple adalah model persamaan regresi linier dengan variabel bebas lebih dari satu. Penggunaan analisis ini didasarkan atas pertimbangan penelitian yang dilakukan untuk menekankan pada pengaruh antara beberapa variabel independen dan variabel dependen.

\section{Hasil dan Pembahasan}

Populasi penelitian ini merupakan kesluruhan jumlah pegawai pada Badan Pendapatan Daerah Provinsi Sumatera Selatan sebanyak 101 responden, yang kemudian diambil sampel sebanyak 51 responden. Berdasarkan hasil survei, menunjukan bahwa responden perempuan mendominasi yaitu sebanyak, 31 orang dibandingkan dengan responden laki-laki sebanyak 20 orang, dengan tingkat usia yang menjadi mayoritas adalah usia 31-40 tahun yang berjumlah 22 orang $(43,14 \%)$, serta pada usia $42-50$ tahun yaitu berjumlah 18 orang $(35,29 \%)$ menjadi mayoritas kedua. Hal tersebut menunjukkan bahwa, sebagian dari responden masih tergolong dalam usia produktif.

Berdasakan nilai yang diperoleh dari persamaan regresi linear berganda adalah $\mathrm{Y}=5,295+$ $0,310 \mathrm{X}_{1}+0,574 \mathrm{X}_{2}$. Konstanta 5,295 artinya jika Konflik $\left(\mathrm{X}_{1}\right)$ nilainya 0 dan Budaya Organisasi nilainya 0, maka kinerja pegawai nilainya sebesar 5,295. Sedangkan koefisien 


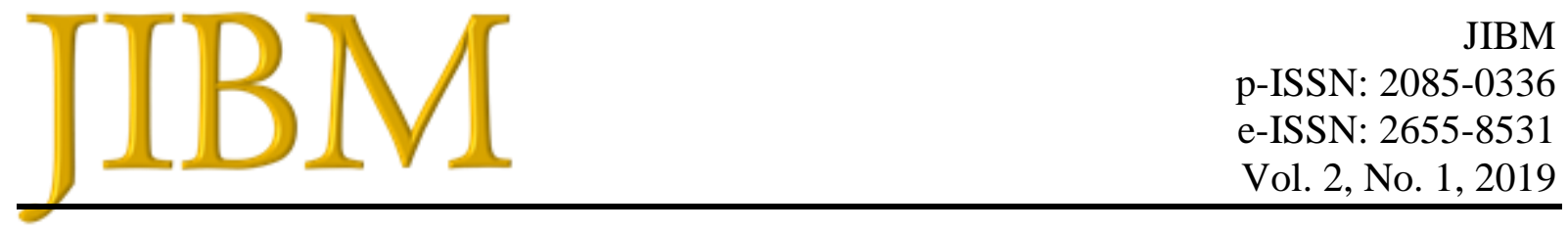

regresi variabel Konflik $\left(\mathrm{X}_{1}\right)$ sebesar 0,310 artinya jika Konflik mengalami kenaikan sebesar satu satuan, maka kinerja mengalami peningkatan sebesar 0,310 satuan dengan asumsi variabel independen lainya (Budaya Organisasi) bernilai tetap. Dari hasil pengujian hipotesis secara parsial, variabel Konflik $\left(\mathrm{X}_{1}\right)$ menunjukkan bahwa terdapat pengaruh secara signifikan positif terhadap variabel Kinerja (Y). Hal tersebut bisa dilihat dari nilai yang diperoleh variabel Konflik yaitu 3,619 > 1,676 yang berarti $t_{\text {hitung }}>t_{\text {tabel }}$ dengan taraf signifikansi 0,001 $<0,05$.

Hasil uji hipotesis variabel Konflik yang berpengaruh positif, sejalan dengan teori yang dikemukakan oleh Robbin yang disebut sebagai the conflict paradox, yaitu pandangan bahwa disuatu sisi konflik dianggap dapat meningkatkan kinerja kelompok. Namun disisi lain, kebanyakan kelompok dan organisasi berusaha untuk meminimalisasikan konflik. Pertentangan inilah yang akhirnya memunculkan pandangan interaksionis (the interactionist view). Pandangan ini cenderung mendorong terjadinya konflik, atas dasar suatu asumsi bahwa kelompok yang koperatif, tenang, damai, dan serasi, cenderung menjadi statis, apatis, tidak aspiratif, dan tidak inovatif. Sehingga, menurut aliran ini, konflik perlu dipertahankan pada tingkat minimum secara berkelanjutan, sehingga menjadikan kelompok tetap bersemangat (viable), kritis-diri (self-critical) dan kreatif (creative) (Royani, 2016).

Pengaruh positif dari konflik tidak lepas dari peran pimpinan dalam mengelola segala aspek kegiatan maupun para pegawai yang ada di organisasi. Dapat dilihat dari tanggapan responden pada kuesioner pertanyaan ke-1 "Pimpinan selalu memberi arahan, jika pegawai mengalami kesalahan dalam komunikasi", sebagian besar responden memberi tanggapan "setuju" dan sebagian lain "sangat setuju" dan "ragu-ragu". Namun tidak ada responden yang menggapi dengan "tidak setuju" maupun "sangat tidak setuju". Tanggapan responden yang demikian, menunjukkan bahwa pimpinan telah berperan baik dalam menyikapi hal-hal yang menjadi indikator konflik.

Kemudian hasil analisis regresi menunjukkan Budaya Organisasi $\left(\mathrm{X}_{2}\right)$ sebesar 0,574 yang diartikan bahwa, jika Budaya Organisasi mengalami kenaikan sebesar satu satuan maka kinerja pegawai mengalami peningkatan sebesar 0,574 satuan dan begitu juga sebaliknya apabila Budaya Organisasi mengalami penurunan satu satuan maka kinerja pegawai mengalami penurunan sebesar 0,574 satuan.

Berdasarkan hasil uji hipotesis secara parsial, untuk variabel Budaya Organisasi $\left(\mathrm{X}_{2}\right)$ didapat nilai thitung sebesar 4,185, sehingga nilai thitung $>t_{\text {tabel }}$ yaitu 4,185 $>1,676$ dengan taraf signifikansi $0,000<0,05$ yang berarti Budaya Organisasi berpengaruh secara signifikan positif terhadap Kinerja pegawai. Selaras dengan penelitian Nel Arianty (2014) dari Universitas Muhammadiyah Sumatera Utara yang menunjukkan bahwa, ada pengaruh yang signifikan positif antara Budaya Organisasi terhadap Kinerja. Berdasarkan hasil tanggapan responden juga telah menggambarkan bahwa, Budaya Organisasi yang ada telah dijalankan dengan baik. Walaupun ketika observasi awal terlihat beberapa pegawai tidak menjalankan budaya yang telah ditetapkan, namun pegawai tetap berusaha untuk menjalin hubungan baik antar sesama. Hal tersebut terlihat dari rata-rata tanggapan responden yang menjawab "setuju" dan "sangat setuju" pada indikator orientasi tim.

Kemudian dari hasil perhitungan Model Summary diperoleh nilai $R$ square sebesar 0,417, sehingga dalam penelitian ini Konflik $\left(\mathrm{X}_{1}\right)$ dan Budaya Organisasi $\left(\mathrm{X}_{2}\right)$ dapat menjelaskan 


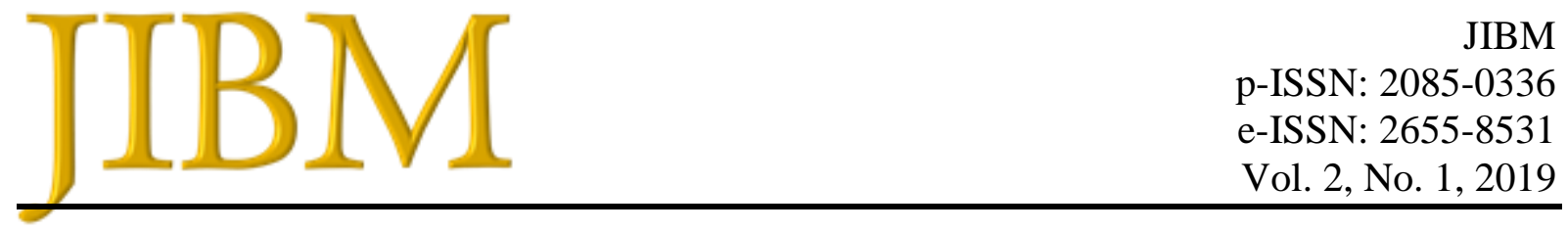

Kinerja pegawai sampai 41,7 \% sedangkan 58,3\% sisanya dipengaruhi oleh variabel lain yang tidak diteliti dalam penelitian ini seperti motivasi, lingkungan kerja dan pelatihan.

Pengaruh Budaya Organisasi $\left(\mathrm{X}_{2}\right)$ lebih besar daripada Konflik $\left(\mathrm{X}_{1}\right)$ terhadap Kinerja pegawai (Y) pada Badan Pendapatan Daerah. Hal tersebut menunjukkan bahwa, Budaya Organisasi merupakan faktor yang lebih dominan berpengaruh terhadap Kinerja pegawai, karena Budaya Organisasi adalah ketetapan yang harus diterapkan setiap saat oleh pegawai. Lalu, dilihat dari hasil uji $F$ didapat nilai $F_{\text {hitung }}$ sebesar 17,180 dengan nilai $F_{\text {tabel }}$ sebesar 3,16 maka nilai $F_{\text {hitung }}$ $>\mathrm{F}_{\text {tabel }}$ yaitu 17,180 > 3.19 dengan nilai signifikansi $=0.000^{\mathrm{b}}<\alpha=0,05 \mathrm{H}_{\mathrm{o}}$ ditolak dan $\mathrm{H}_{\mathrm{a}}$ diterima, artinya ada pengaruh yang signifikan antara Konflik dan Budaya Organisasi terhadap Kinerja Pegawai.

\section{Simpulan dan Saran}

Berdasarkan hasil analisis dan pembahasan mengenai Pengaruh Konflik dan Budaya Organisasi terhdap Kinerja Pegawai pada Badan Pendapatan Daerah Provinsi Sumatera Selatan yang telah peneliti uraikan pada bab sebelumnya, maka pada bab ini peneliti menarik kesimpulan sebagai berikut:

1) Berdasakan nilai yang diperoleh dari persamaan regresi linear berganda adalah $Y=5,295+$ $0,310 \mathrm{X}_{1}+0,574 \mathrm{X}_{2}$. Artinya variabel Budaya Organisasi $\left(\mathrm{X}_{2}\right)$ lebih besar memberikan pengaruh pada Kinerja pegawai dari pada Variabel Konflik $\left(\mathrm{X}_{1}\right)$.

2) Dari koefisien Korelasi (r) yaitu sebesar 0,646 berarti berada pada range 0,60-0,799. hal ini menunjukkan bahwa korelasi antara Konflik $\left(\mathrm{X}_{1}\right)$ dan Budaya Organisasi $\left(\mathrm{X}_{2}\right)$ terhadap Kinerja Pegawai (Y) memiliki hubungan yang kuat.

3) Berdasarkan perhitungan tersebut nilai $\mathrm{R}$ square sebesar 0,417 sehingga dalam penelitian ini Konflik dan Budaya Organisasi dapat menjelaskan Kinerja pegawai sampai 41,7 \% sedangkan 58,3\% sisanya dipengaruhi oleh variabel lain yang tidak diteliti dalam penelitian ini, seperti motivasi, lingkungan kerja, pelatihan dan lain-lain.

4) Berdasarkan hasil uji hipotesis secara parsial, variabel Konflik $\left(X_{1}\right)$ menunjukkan bahwa terdapat pengaruh yang signifikan positif terhadap variabel Kinerja (Y). Hal tersebut bisa dilihat dari nilai dari $t_{\text {hitung }}>\mathrm{t}_{\text {tabel }}$ yaitu 3,619 $>1,676$ dengan taraf signifikansi lebih kecil dari 0,05 yaitu 0,001

5) Berdasarkan hasil uji hipotesis secara parsial, variabel Budaya Organisasi ( $\left.\mathrm{X}_{2}\right)$ menunjukkan bahwa terdapat pengaruh yang signifikan positif terhadap variabel Kinerja (Y). Hal tersebut bisa dilihat dari nilai dari $t_{\text {hitung }}>t_{\text {tabel }}$ yaitu 4,185 $>1,676$ dengan taraf signifikansi lebih kecil dari 0,05 yaitu 0,000

6) Berdasarkan tabel yang diperoleh dari uji $F$ menjelaskan nilai $F_{\text {hitung }}$ sebesar 17,180 dengan nilai $F_{\text {tabel }}$ sebesar 3,16 maka nilai $F_{\text {hitung }}>F_{\text {tabel }}$ yaitu 17,180 $>3.19$. Nilai signifikansi $=$ $0.000^{\mathrm{b}}<\alpha=0,05$ maka $\mathrm{H}_{\mathrm{o}}$ ditolak dan $\mathrm{H}_{\mathrm{a}}$ diterima, artinya ada pengaruh yang signifikan antara Konflik dan Budaya Organisasi terhadap Kinerja Pegawai.

\section{Daftar Pustaka}

Arianty, N. (2014). Pengaruh budaya organisasi terhadap kinerja pegawai. Jurnal Manajemen \& Bisnis, 14(22).

Edison, E., Anwar, Y., \& Komariyah, I. (2017). Manajemen Sumber Daya Manusia. Bandung: Alfabeta.

Handoko, H.T. (2011). Manajemen: Edisi Kedua. Yogyakarta: BPFE.

Kurniawan, A. (2014). Metode Riset Untuk Ekonomi dan Bisnis. Bandung: Alfabeta. 
Mansur, L. (2013). Karakteristik Budaya Organisasi dan Hubungannya dengan Kinerja Organisasi pada Lembaga Penjamin Mutu Pendidikan di Indonesia.

Marwansyah. (2012). Manajemen Sumber Daya Manusia. Bandung: Alfabeta.

Putra, A.K.U. (2015). Gaya Manajemen Kompromi dalam Menekan Konflik antar Kelompok. Skripsi. Universitas Islam Bandung. Bandung.

Royani, A. (2016). Manajemen Konflik. IAIN Jember. Jawa Tengah.

Septianto, D. (2010). Pengaruh Lingkungan Kerja dan Stres Kerja Terhadap Kinerja Karyawan: Studi pada PT Pataya Raya Semarang. Skripsi. Universitas Diponegoro. Semarang.

Sugiyono. (2016). Metodologi Penelitian Manajemen. Bandung: Alfabeta.

Umam, K. (2012). Manajemen Organisasi, Cetakan Ke Satu. Bandung: Pustaka Setia.

Wibowo. (2014). Prilaku dalam Organisasi. Jakarta: PT Raja Grafindo Persada.

\section{Copyright Disclaimer}

Copyright for this article is retained by the author(s), with first publication rights granted to the journal. 